\title{
Loyalty marketing and loyalty cards: a study of the Italian market
}

\author{
Elena Cedrola \\ Department of Economics and Financial Institutions, \\ University of Macerata, Macerata, Italy and \\ University Cattolica of Milano, Milano, Italy, and \\ Sabrina Memmo \\ Department of Economics and Financial Institutions, \\ University of Macerata, Macerata, Italy
}

Loyalty
marketing and
loyalty cards

205

Received April 2008

Revised February 2009

Accepted November 2009

\begin{abstract}
Purpose - Loyalty programmes are an important tool with which retail companies manage relationships. While the last 15 years have seen a broad dissemination of loyalty programmes in new sectors and new countries, since the early 2000s, both in the academic and managerial world, the power of loyalty programmes to stimulate retention and support loyalty, has been brought into question. The purpose of this paper is to focus on these elements, analyzing data collected on a sample of loyalty cardholders.

Design/methodology/approach - The paper presents the results of an exploratory study focused on a sample of loyalty cardholders by means of telephone interviews.

Findings - The empirical data demonstrate that loyalty is not created and supported by a loyalty programme and prove how weak and limited such programmes are, especially point collection programmes. Programme effectiveness can however be achieved if there is a continuous search for differentiation and through reduced loss (discounts) and extra gain (prizes) initiatives.

Research limitations/implications - The analysis of what customers expect and how they behave towards programme innovations needs further empirical detail. For the future, qualitative research should be provided, as well as analyses of a higher number of socio-demographical variables and life-styles.

Originality/value - The paper provides empirical data on customer behaviour and opinion towards loyalty programmes.
\end{abstract}

Keywords Italy, Loyalty schemes, Consumer behaviour

Paper type Research paper

\section{Loyalty marketing: origins and developments}

Over the last 20 years, loyalty marketing has become an important tool in the competitive differentiation strategy of commercial distributors, where, in a context of market maturity, competitive pressure has increased not only in intertype competition, but also in sales formats (Lugli and Pellegrini, 2005).

Significant changes in demand, an inability to cope with qualitative development and growth in supply, increasingly customised and unpredictable purchasing and consumption behaviour, have created further challenges for distribution companies.

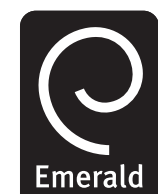

International Journal of Retail \& Distribution Management Vol. 38 No. 3,2010 pp. $205-225$ (C) Emerald Group Publishing Limited 0959-0552 
IJRDM

38,3

206
In fact, retail companies can develop and maintain a solid competitive advantage if they are able to respond to market needs and changes more effectively than their competitors (Worthington, 1996; Lugli and Ziliani, 2004).

If modern distribution has established the basis of its development on the standardization and globalization of the offer in a largely changed competitive context, then a better understanding of customers and a more appropriate use of information to define the commercial offer has become the new paradigm of trade marketing.

Some theoretical studies have given the role of marketing a new definition: to build, maintain and enhance relationships with customers (Ferrero, 1992; Ziliani, 1999; Farinet and Ploncher, 2002; Cedrola, 2006), in order to meet the requirements of all parties participating in the transaction (Grönroos, 1990; Invernizzi, 2000; Busacca, 2002). However, the most challenging task of a marketing operator is the:

[... ] creation of "loyal customers", who will probably never turn to competitors because they are satisfied with the retail company they have chosen and because they feel considered and appreciated by them (Berry and Parasuraman, 1992, p. 179).

Therefore, loyalty marketing can be regarded as a management process that aims to identify, maintain and increase the share of wallet of top customers (Berry et al., 1983) as well as the lifetime value, through the management of a relationship approach typical of a loyalty programme (Woolf, 2002), defined as a set of actions and operative marketing instruments with which a retail company manages relationships. Among these tools, loyalty cards are the main vehicle for customer targeting initiatives.

Loyalty programmes originated in the airline sector in the $1980 \mathrm{~s}$, when AAdvantage, the programme pioneered by American Airlines, was first launched. Programmes developed intensely in the 1990s when technology and new media flourished. In the last 15 years, loyalty programmes have rapidly become disseminated in an increasing number of industries and countries, while now also expanding towards the east (Ziliani, 2004b).

In mature markets in North America and Europe, loyalty programmes involve millions of customers owning loyalty cards. In the USA, 90 per cent of consumers take part in 2,250 different loyalty programmes (Berman, 2006).

In 2002, 20 distribution companies with over one million registered customers were monitored in Europe: six of these had more than five million card-holding customers in their database.

In Italy, since the early 2000s, the biggest 20 distributors manage loyalty programmes involving over one million registered customers with around 20 million active cards in all sectors (Ziliani, 2004a).

However, since the early 2000s, the loyalty aspect of loyalty programmes has been somewhat brought into question (Wright and Sparks, 1999; Sandberg, 2002). Responses of managers are contentious when asked, "which is more effective, EDLP (every day low price) or the loyalty programme?" (Rubach, 2002). The few cases where loyalty programmes have been abandoned in favour of EDLP (Safeway, Asda), have highlighted the risks and mistakes in the implementation of programmes.

However, according to the Osservatorio di Parma (Italy), whose research is focused on loyalty programmes in Italy, most of the big names are not planning to abandon their programmes, although management have doubts about future developments with no real intention to innovate (Ziliani and D'Onofrio, 2006). 
According to Dowling and Uncles (1997), retail companies are not willing to abandon their own loyalty programmes for fear of loosing sales. On the other hand, they are reluctant to invest further in loyalty programmes as they can easily be imitated by competitors (Sharp and Sharp, 1997; Dowling, 2002; Meyer-Waarden and Benavent, 2006).

In fact, it is this imitation trend, rather than research, innovation and diversification, that has produced a wide range of very similar loyalty programmes, resulting in their reduced effectiveness (Lugli, 2006; Meyer-Waarden, 2007) and incentivizing opportunistic behaviour in customers (Berman, 2006).

The power of loyalty programmes to spur retention and support loyalty has also been brought into question by scholars. Empirical contributions on the topic show contradictory results: from an insignificant influence on repeat purchases (Magi, 2003) to the acknowledgement of the influence of loyalty programmes, especially when prizes can be obtained (Kivetz et al., 2006).

According to Meyer-Waarden (2007), there is a positive correlation between owning a loyalty card, the amount of expenditure and the length of the relationship between a customer and their focal store. However, owning several cards from different competitors has a negative impact on loyalty. Loyalty programmes are undoubtedly valid, especially when correctly planned and implemented. Limitations and unfavourable results concern only their usage.

The loss of effectiveness of loyalty programmes is due to the poor innovation and differentiation of programmes. A study carried out in a city in the USA demonstrated that just 4 per cent of the interviewed consumers participating in the loyalty programmes of three supermarkets, perceived only a slight difference among the programmes (Bellizzi and Bristol, 2004).

Among the initiatives adopted in loyalty programmes, if the point collection programmes are easily copied and their distinguishing features eroded (Ziliani and D'Onofrio, 2006), then the discount operations reserved for card holders are also widely exploited and standardized (Berman, 2006). Price is the primary reason customers choose more loyalty cards, causing a negative impact on the loyalty function of a card (Rubach, 2002; Meyer-Waarden, 2007).

Several authors believe that most of the problems affecting loyalty programmes relate particularly to the management of the points programme: from the redemption of prizes to changes in programme rules (Friedman, 2003).

The future success of these programmes will depend on a reinforcement process based on understanding the development trends in loyalty programmes. Recent studies explored all the perspectives of loyalty programmes and perceived the development lines in diversifying promotional initiatives on micro-groups of customers (Ziliani and Bellini, 2004; Ziliani and D'Onofrio, 2006; Hawkins, 2006), evolving loyalty programmes into coalition marketing (Lugli, 2006; Baird, 2007) and finding a new interpretation for rewards in the point collection programme. These rewards become "emotional prizes" and their aim is to kindle customer desire and inspire loyalty (Capizzi et al., 2004; Cuthbertson, 2006-2007; Vence, 2006; Gable et al., 2008).

\section{Open questions on loyalty cards}

Examination of literature on this topic revealed some crucial issues and prompted a number of questions: 
IJRDM

38,3

208

- Does a card really create customer loyalty?

- How, and how much, does the possession of several cards affect loyalty?

- How, and how much, do rewards affect participation in loyalty programmes?

In light of the theory and the questions indicated, the present contribution will focus on these statements:

- Owning more loyalty cards discourages loyalty to a retail company.

- A generalized use of price promotions in loyalty programmes increases disloyalty to programmes.

- The more experience-driven a reward is (aspiring reward), the more attractive a loyalty programme is.

To this end, an empirical enquiry was carried out on a sample of loyalty cardholders of an Italian food retailer, by means of telephone interviews.

In the next chapter, we provide details on the research method and describe the most significant empirical findings. Finally, the theories mentioned in the first part of the paper, mostly referred to the supermarket loyalty policy, will be discussed in the light of the empirical results.

\section{Research methodology}

The investigation was carried out on the loyalty card database of an important Italian retail company active in the Italian regions of Marche, Abruzzo, Molise, Puglia and Basilicata (Southern Italy).

The population studied is composed of all the "active" owners of a loyalty card in the period September-November 2004. The 606 customers interviewed, representing 0.57 per cent of the population, were selected through stratified random sampling. For this purpose, they were divided into homogeneous groups of four variables:

(1) customer contribution to the company turnover, which is defined by dividing customers into sections according to the average weekly spend in the considered period: Segment A (with € > 100, average weekly spend); Segment B (€50-99.99); Segment C (€25-49.99); Segment D (€ < 24.99);

(2) province of residence (L’Aquila, Ascoli Piceno, Campobasso, Chieti, Foggia, Isernia, Macerata, Pescara e Teramo);

(3) gender; and

(4) age, the different age groups are: 16-25, 26-35, 36-50, 51-65 and 66-90 years old.

The match of these variables resulted in 352 different groups. From these a random selection for each stratum was calculated and included in the sample. The sample of 606 interviewed customers was divided into:

- The "average weekly spend" variable. About 3.1 per cent belong to Segment A, 24.3 per cent belong to Segment B, 43.4 per cent to Segment C and 29.2 per cent to Segment D.

- The geographical variable. About 13.2 per cent of the interviewed subjects live in the province of Pescara, 11.5 per cent in the province of Ascoli Piceno, 11.4 per cent in the province of Teramo, 2.8 per cent in the province of L'Aquila, 
13.7 per cent in the province of Campobasso, 29.5 per cent in the province of Chieti, 16.7 per cent in the province of Foggia, 1 per cent in the province of Isernia and 0.2 per cent in the province of Macerata.

- The gender variable. About 77.6 per cent of the interviewed subjects are female and 22.4 per cent are male.

- The age variable. About 1.7 per cent of the interviewed subjects belong to the youngest age group (16-25), 16.2 per cent from 26 to 35 years, 43.1 per cent from 36 to 50 years, 26.5 per cent from 51 to 65 years and 12.5 per cent from 66 to 90 years.

The composition of the sample reflects the socio-demographic characteristics of the territory and the customers of the chosen retailer.

The majority of the retailer's points of sales are supermarkets and small shops that are mostly located in the city centres. They are generally preferred by old people who conceivably have less possibilities to move.

For this reason there is a high percentage of customers who are aged 65-90 years.

The data were collected in the period February-April 2005 by means of semi-structured phone interviews with questions divided into five topical areas (Table I). The typology of questions varied: some were open questions, others were yes-no questions and others had a multiple-choice structure.

The variables we considered are those that are generally adopted by Italian retailers for the analysis of the spread and use of loyalty cards. They are also considered the most important ones for this kind of analysis (Woolf, 1996, 2002).

The topics that were investigated in the questionnaire, are both relevant for empirical contribution and for the retailer who gave us internal data.

\section{Possession of loyalty cards in terms of quality and quantity}

The first research area, intended to illustrate the diffusion of loyalty cards in terms of quantity, usage and typology, has shown that 55.6 per cent of the interviewed subjects own and use more than one card. On average, each person interviewed owns 1.6 cards.

Quality and quantity of loyalty cards

Reasons for choosing a loyalty programme

Satisfaction of loyalty programmes

Dissatisfaction of loyalty programmes

Expectations on new services and discounts for loyalty cardholders
Quantity

Use

Typology

Extra gain promotions

Reduced loss promotions

Collection

Joker points

Discounts

Prizes

Co-marketing

Reward

Assistance

Information

Preferences and suggestions on discounts

Preferences and suggestions on additional services
Table I. Macro-topics analyzed marketing and loyalty cards

209 
IJRDM

38,3

210
According to this first empirical data, and considering the different locations that the interviewed subjects came from, we can state that there are differences among the provinces studied. The tendency to own several cards is generally associated to how significant modern distribution is in the area and how relevant the existing formats are. The tendency to several cards is lower in the province of Foggia, where the weight of the super + hyper retail formats (supermarkets + hypermarkets) is 21 per cent of the whole distribution network (the lowest recorded value of all the provinces studied), whereas the highest level is in the province of Teramo, where the weight of the more innovative formats of modern distribution is 38 per cent. To the contrary, there is no positive relation between the number of retail companies operating in a specific area and the tendency to own several cards (Pearson correlation is -0.175 significant at the 0.01 level). Considering once again the provinces of Foggia and Teramo, the data show that there are 15 modern distribution groups with 35 retail outlets in the province of Foggia, a situation that offers customers a greater choice than in the province of Teramo, where 12 modern distribution groups have a total of 19 retail outlets.

The empirical evidence highlights the fact that the distribution formats (rather than brand names) affect the number of loyalty cards owned. This is supported by a qualitative analysis of the retail brands referring to their formats and the tendency to own loyalty cards (Figure 1)[1].

Customers owning a loyalty card of the retail company analyzed are inclined to also own the card of the hypermarket operating in the same area (Group A). Customers consider hypermarkets as an alternative to the retail company whose core business is in the supermarket format. Moreover, the customers interviewed have loyalty cards of the "follower" format and/or the "leader" format according to the market share held by the partner in the various market contexts (Group B). A low number of loyalty cards are owned (Group C) in other retail companies which are essentially format competitors.

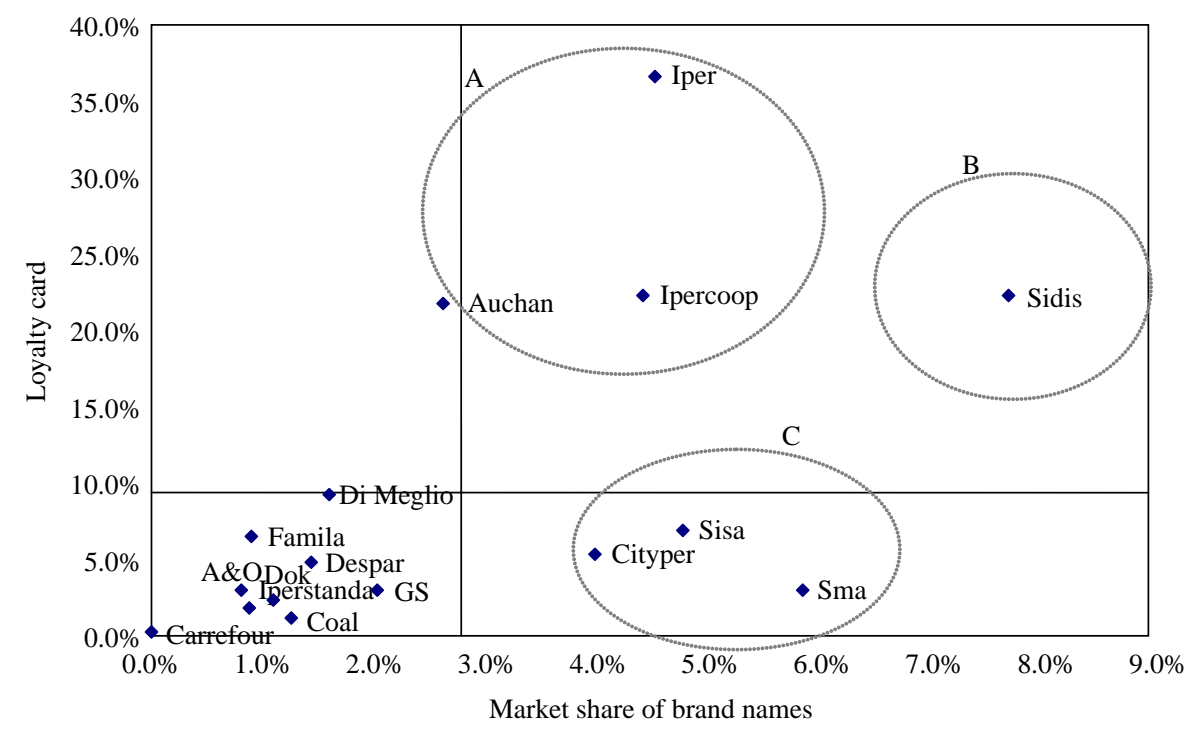

Figure 1.

Loyalty cards and retail companies 
From this first data screening, we can affirm that:

- Customers are inclined to go to a group of sales outlets, whose formats are generally different, in order to satisfy their propensity for variety. Customer loyalty is a relative loyalty (Mauri, 2000).

- Customers seem to be more opportunistic when the competitive pressure is higher. In such circumstances, loyalty cards are supposed to reduce itinerancy, but do not seem to totally solve this problem.

As for the number of cards owned and used, 55.6 per cent of the interviewed subjects claimed to own more than one card. The following picture emerged:

- 2 cards 53.8 per cent;

- 3 cards 31.5 per cent;

- 4 cards 10.8 per cent;

- 5 cards 2.1 per cent; and

- $>5$ cards 1.8 per cent.

The number of loyalty cards is inversely proportional to the economic value of a customer. The highest spenders own one, or at most, two cards - besides the retail company's card - whereas customers belonging to Segments C and D may own up to five or more cards.

If we consider all card types that customers of the different segments have (Table II), we see that the variety of cards increases as the spend in segments decreases. In the same way, cards issued by hypermarkets become more and more significant thereby proving the intertype competition mentioned above.

There is a difference in the number of cards used with respect to the customer's age: younger customers are generally more inclined to own more than one card, as can be seen from the data shown in Figure 2 (elaboration based on the total amount of interviewed subjects).

In this case, we have to consider that older customers did not grow up with loyalty cards (Pearson correlation between the age group 66-90 and the ownership of one card is 0.177 significant at the 0.01 level). The older customers also tend to shop on a limited number of places maybe because of limited mobility.

The age variable also affects the type of cards owned in addition to the preference for particular sales formats. The customers in the two younger age groups (16-25 and 26-35) own cards issued by hypermarkets (99 per cent cards on average), in the older age groups (51-65 and 66-90) there is an average 59 per cent predominance of cards issued by supermarkets and superettes (small supermarkets).

Table III shows the type of cards owned by customers by age groups. It appears that both younger and older customers have a very clear preference of outlets, whereas the middle age groups do not have problems in owning and using a greater number of cards issued by several retail companies (Pearson correlation between the age group 36-50 and the ownership of one card is -0.114 significant at the 0.01 level, while Pearson correlation between the same age group and the ownership of four cards is 0.157 significant at the 0.01 level). These customers, generally including purchase managers, are the most opportunistic.
Loyalty
marketing and
loyalty cards

211 
IJRDM

38,3

212

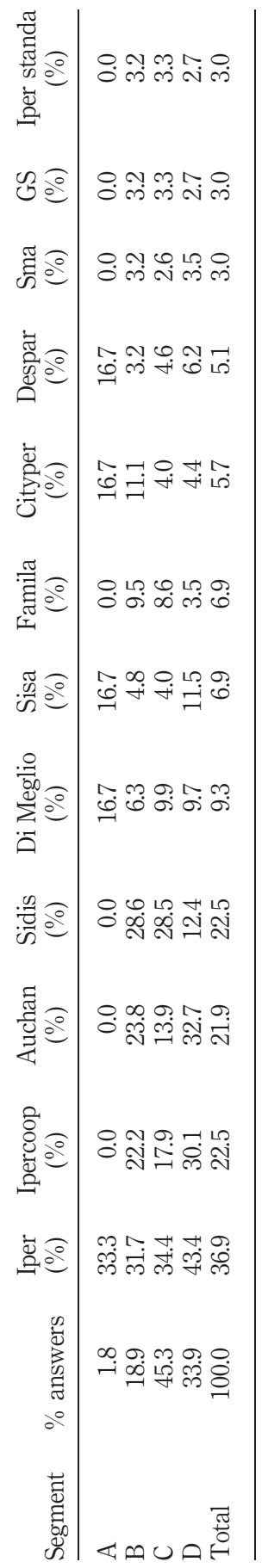

Table II.

Loyalty card types by segment 


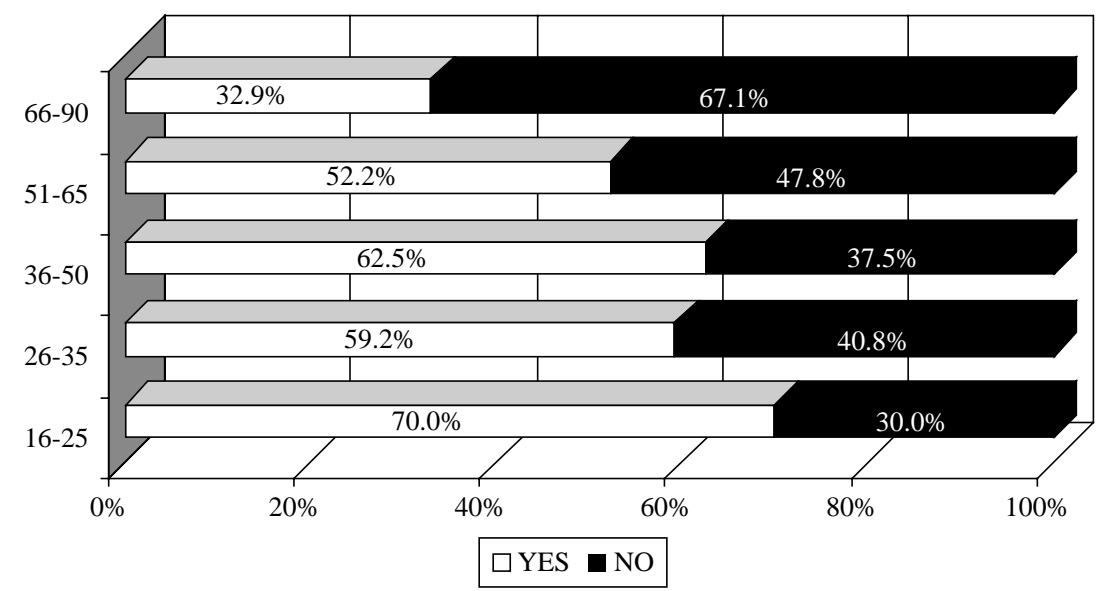

Note: Percentage incidence of answers related to age group/people interviewed by age

\section{Loyalty marketing and loyalty cards}

213

With regard to gender, we found that 56.4 per cent of women own more than one card compared to 52.9 per cent of men. This is because in Italy women generally do the shopping and are more likely to be attracted by competitors.

\section{5 . Why choose a loyalty programme?}

The study also investigated the motivations behind choosing a loyalty programme, first by gathering spontaneous answers and then by giving prompts and precise suggestions.

In spontaneous answers, most of the interviewed subjects (95 per cent) stated that they used loyalty cards to collect points and to receive special discounts. A small percentage of customers (2.5 per cent) were interested in discounts only, and a much smaller percentage used loyalty cards only to collect points.

When given two alternatives (taking part in points collection or special discounts), the majority of interviewed subjects favoured discounts (70.8 per cent).

Customers (17.2 per cent) claimed to use a card only to collect points and quite a large percentage (12 per cent) use a card for both discount and points or else do not have a specific motivation for using it.

The geographical analysis shows that the point collection programme has a greater appeal in closed areas, where competition among retail companies is less intense (Ascoli Piceno, 22.9 per cent; Foggia, 20.8 per cent), whereas in areas with price-based hyper-competition a customer is more inclined to look for convenience (Campobasso, 73.5 per cent; Chieti, 73.2 per cent).

When the results are divided into segments by spend (Figure 3), we notice that customers belonging to Segment B (25.2 per cent) are most interested in point collection. When compared with other groups, they show a lesser interest in discounts, although the percentage remains high and at greater levels than those recorded for points (66.7 per cent). Segment D is the segment that gives greater importance to discounts (76. 3 per cent) and this is confirmation of what other topical studies have hitherto claimed. 
IJRDM

38,3

214

\begin{tabular}{|c|c|}
\hline 焉 & 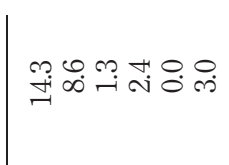 \\
\hline 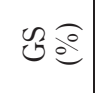 & 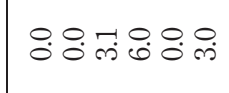 \\
\hline 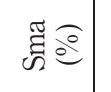 & 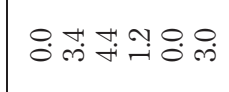 \\
\hline & 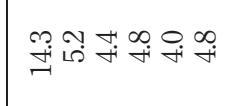 \\
\hline & 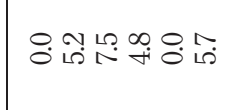 \\
\hline & 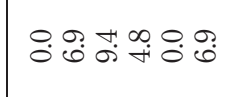 \\
\hline 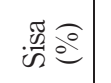 & 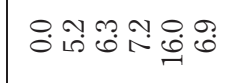 \\
\hline 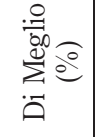 & 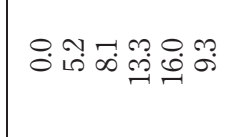 \\
\hline 总。 & 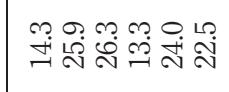 \\
\hline 惡 & 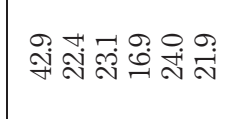 \\
\hline 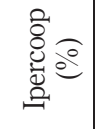 & 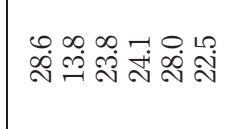 \\
\hline 总。 & 孚 \\
\hline 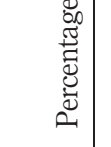 & 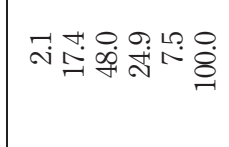 \\
\hline & 品 \\
\hline
\end{tabular}

Table III.

Loyalty card by age group and retail company 


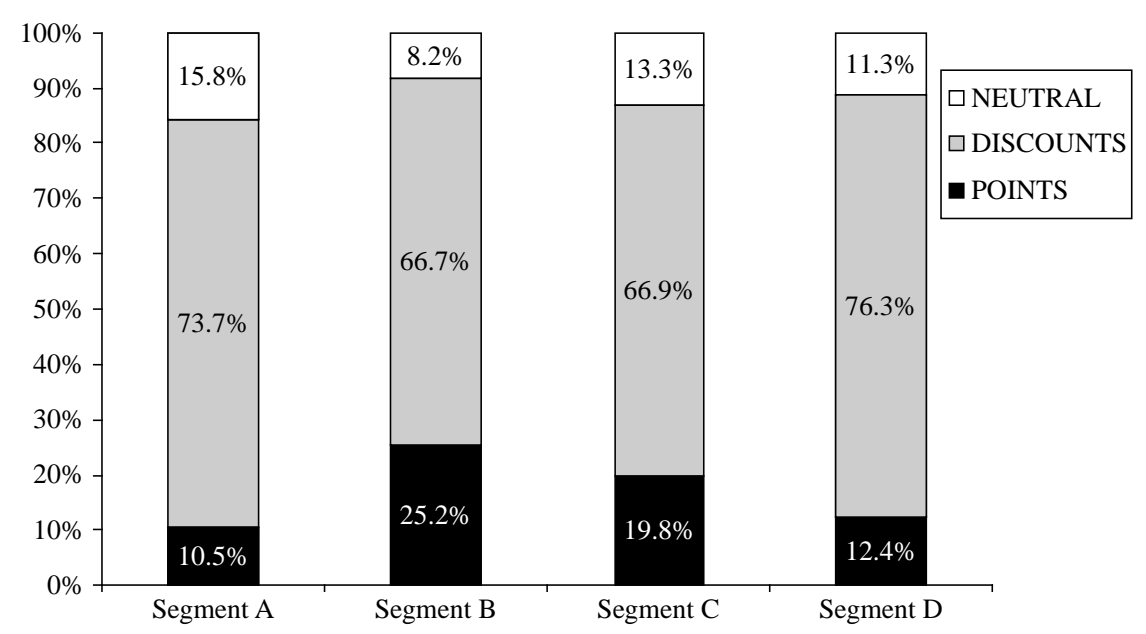

\section{Loyalty marketing and loyalty cards}

215

Note: Answers related to interviewed segments

High spending customers (Segment A) do not show any particular inclination to collect points. It should be noted, however, that results discussed thus far have been partly mitigated by the above average percentage of top customers who attribute the same value to both types of promotional initiatives of loyalty cards (15.8 per cent, average: 12.1 per cent).

This demonstrates that customers in Segment A are the most frequent users of loyalty cards for both points and discounts but without expressing any clear preference.

In this case, the analysis of the data with reference to the gender variable shows a homogeneous situation: the percentage of men and women with the same attitude towards points and discounts is substantially uniform. This result is noteworthy as it contradicts the axiom that women are more interested in collecting points than men are, so much so that prizes are predominantly aimed at female customers.

When the interviewed subjects are divided into age groups (Figure 4), we note that younger customers are more inclined towards point collection (30 per cent) than those between 36 and 65 years of age (21.5 per cent).

Interest in loyalty discounts is relatively uniform: the percentages range from 70 per cent for younger customers and 73.9 per cent for the 51-65 age group. The low percentage of older customers who are interested in discounts (50 per cent of an average of 67.6 per cent) is surprising when considering the economic problems that this age group often complain of. This result should be considered in light of the "neutral" customers, which, in the case of customers between the ages of 66 and 90, has a much higher than average value (26.3 per cent of an average of 10.9 per cent). This may be attributed to an insufficient perception of the value and difference between the different types of promotions, which is confirmed by the fact that in going down the age scale, the percentage of those expressing a motivational preference for the use of cards diminishes.

Further considerations emerge when analyzing the motivations behind loyalty card use: 
IJRDM

38,3

\section{6}

Figure 4.

Why use a loyalty card: details per age group

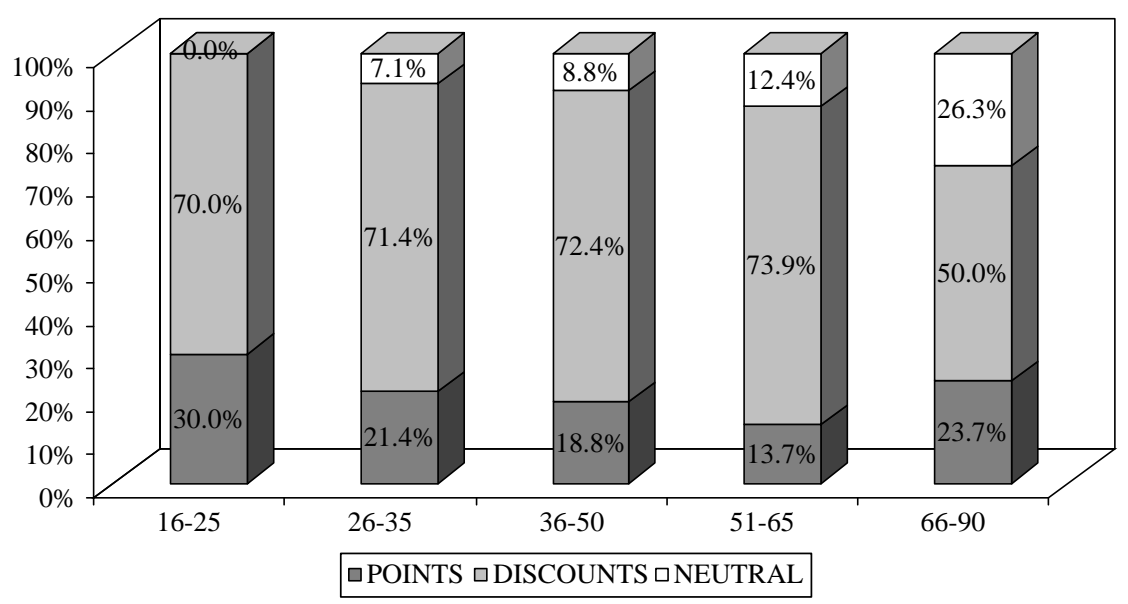

Note: Answers relate to interviewed age groups

- When subscribing to a card, a customer is inclined to maximize all the advantages offered in terms of point collection as well as paying attention to reduced loss initiatives.

- Discounts are the most important reason for customers to subscribe to a card.

- Interviewed customers (12 per cent) did not specify why they use a card. The highest percentage of "neutral" customers is found in the top customer and older age groups. To explain this situation we conjecture that Segment A customers effectively consider the two motivations equivalent, while the other group, especially the elderly, are unable to perceive the value and difference between the promotional initiatives.

The minor interest that the top customer segment has in the programmes should be monitored and studied further, also in consideration of the fact that incentive programmes are one of the key elements for retailers to reward their best customers (Woolf, 2002).

\section{How satisfactory or unsatisfactory are loyalty programmes?}

The successive research area concerns satisfaction and dissatisfaction of loyalty programmes. On this issue, the study analyzed:

- how popular and satisfactory promotions linked to discount (reduced loss) and prizes (extra gain) are for loyalty card holders; and

- from the spontaneous answers, how customers explain their satisfaction or dissatisfaction with loyalty programmes.

The level of acceptance of sales promotions addressed to the holders of loyalty cards was tested by asking them to express their opinion with a score from 1 (min) to 10 (max) to each promotion. 
In order to value how much customers were dissatisfied, they were asked the question: "Have you experienced any gaps or inefficiencies while using your fidelity card?"

As to specific promotional initiatives, a substantial amount of information was gathered on loyalty discounts and "jolly" products, i.e. products bearing the joker symbol, at the point of sale or in promotional leaflets, which award additional bonus points in excess of spend and facilitate the collection of points at a faster rate.

An absolute majority of interviewed subjects believe that loyalty discounts are relatively convenient (62.4 per cent) and a comparatively high percentage of customers believe that this initiative is very advantageous (26.5 per cent). The percentage of customers who believe that the initiatives have a low (9.4 per cent) or insignificant (0.7 per cent) level of convenience is small.

The perception of convenience is higher when considering the opinions expressed by 70.8 per cent of respondents who use the card mostly to access discounts: 28.9 per cent consider them very advantageous, while only 0.2 per cent do not.

However, loyalty cardholders show little enthusiasm for products offering additional bonus points, 48.8 per cent of interviewed subjects show moderate interest while a high percentage show little (31.9 per cent) or insignificant (11.4 per cent) interest.

This is further confirmed when considering that 17.2 per cent of the sample use the card mainly to take part in point collection. A growing number of customers think the initiative is quite interesting (54.9 per cent), a reduced number think it very interesting (3.5 per cent) and an increased number consider "jolly" products (15.9 per cent) insignificant.

With regards to dissatisfaction of loyalty programmes, most complaints refer to the point collection programmes. Delay in delivering prizes is the primary issue (50.8 per cent), followed by a poor level of information (deadlines and cancellation of accrued points, 23.8 per cent). Complaints ( 5 per cent) concern problems with prizes that have been pre-booked, deleted or replaced. There are also issues with the actual use of the card, such as inconsistency between effective amount of points and delays in updating points (12.9 per cent), transfer of points from one card to another (5.0 per cent), difficulties in case of lost cards (2.5 per cent).

In conclusion, whilst cardholders are satisfied with the discounts offered, there is relatively low interest in promotions offering additional points. The most significant criticisms concern the way the programme is managed.

\section{Expectations on new services and discounts for loyalty cardholders}

The third section of the questionnaire shows all the preferences and suggestions expressed by customers on the services and discounts they would like to have included in a loyalty scheme. Interviewed subjects were given information on different types of discounts offered by retail companies (i.e. discounts on transport, cinema, theatre, sports facilities, holidays), as well as alternative services (home delivery, purchase of groceries over the phone, courses in the retail outlet, loyalty cards used for payment, postponement of payment or payment by instalments).

Figure 5 shows their responses: the preference for reduced loss rather than extra gain initiatives.

Another aspect, we analyzed was the conversion of promotional money (points) into conventional money (discounts). This option obtained wide consensus: 72.1 per cent of interviewed subjects were very interested in this proposal and the number who indicated a low (8.3 per cent) or insignificant (5.1 per cent) interest was relatively small.
Loyalty
marketing and
loyalty cards

217 


\section{$\mathrm{IJRDM}$ \\ 38,3}

\section{8}

Figure 5.

Level of preference for discounts and additional services

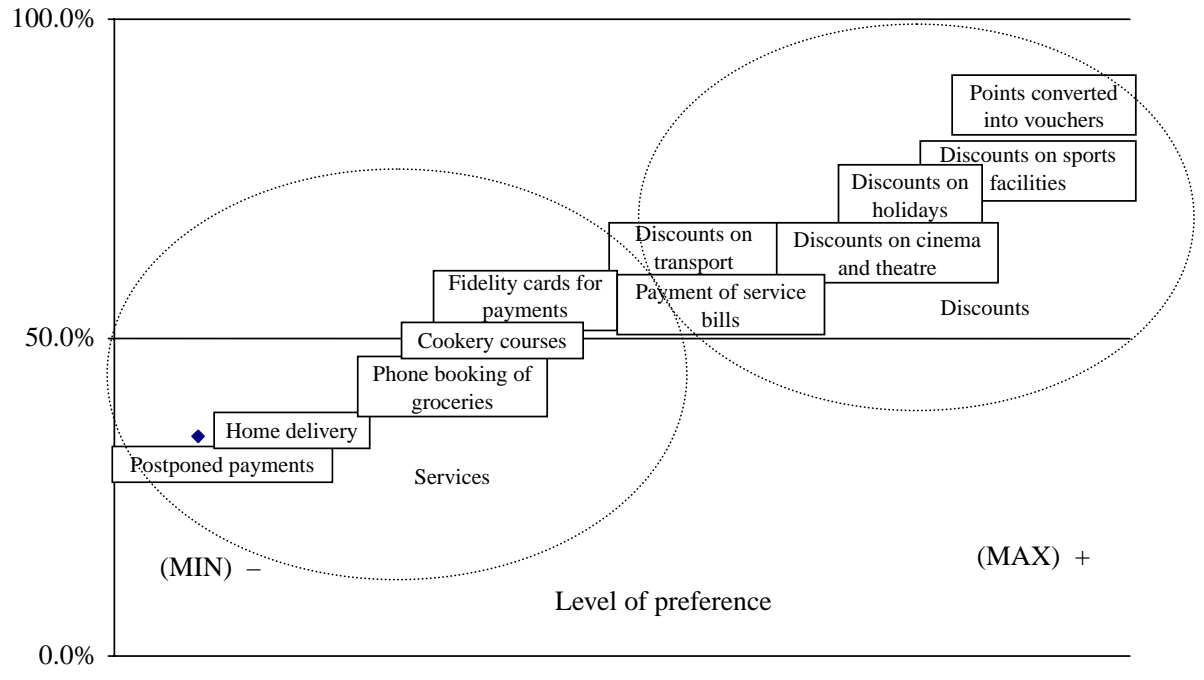

This is an ulterior confirmation that customers are more interested in discounts than in points.

When customers are divided into segments related to how much they contribute to turnover (Groups A, B, C and D), the results show a substantial alignment of opinions in the different segments - 80 to 90 per cent of the sample answered positively ("good" and "quite good").

To sum up, discounts on sports facilities were judged best: over half the sample (57.9 per cent) were very interested in such a promotion, whilst 13.4 per cent were quite interested, 8.6 per cent were little interested and 20.1 per cent not interested.

Discounts on holidays were positively judged by 51.2 per cent, whereas 20 per cent were not interested.

About 50 per cent of people interviewed believe that discounts on cinema and theatre tickets are very interesting. The percentages of those who expressed a different opinion are: quite interested (16.3 per cent), little interested (10.7 per cent), not interested (23 per cent). Finally, discounts on transport were the least appreciated, although the percentages of those who considered them positively ("very interested" 45.9 per cent, "quite interested" 16 per cent) are higher than those who showed "little" (12.2 per cent) and "no" interest (25.9 per cent).

These results, which take into account the "spend segment" variable, are very surprising: we can state that, for all options analyzed, the top customers are always among those least interested in loyalty cards.

The analysis of age groups shows that negative judgements derive predominantly from older customers: on average, 71.1 per cent of interviewed subjects in the 66-90 age group do not appreciate these kinds of initiatives. Positive interest, instead, derives from the younger age groups (16-25 and 26-35).

In analyzing the services that cardholders were offered, home delivery and purchase of groceries over the phone were not greatly appreciated: very interested (23.9 per cent), quite interested (12.1 per cent), little interested 16.5 per cent. The least interested are the elderly: 65.8 per cent say they are not interested at all. This should be interpreted in 
light of the importance that senior citizens attribute to shopping as a time for socializing, recreation and physical activity.

The possibility of using a loyalty card for payment or for postponing payment appears less interesting to those in Segment A.

As to payment of service bills, TV licence and car tax, the percentage of those interested ("very interested" 43.7 per cent, "quite interested" 11.4 per cent) is slightly higher than those who have a negative opinion ("little interest" 10.7 per cent, "no interest" 34.2 per cent). The percentage is the same for cookery courses held by the supermarket. The segment analysis also showed that Segments B and C are the most interested in using these services, whereas Segment A has negative opinions on all the options.

It is clear that the top customers are least interested in promotions that are not specific to supermarket activity. This group expects a supermarket to be highly efficient in its product range, services, quality, best quality-price ratio, elements that need to be continuously monitored by the retail company in order to achieve excellence. This confirms the need to know one's customers, their expectations of a retail company and, in particular, the different type of sales formats. The differences in the age variable demonstrates how highly heterogeneous customers are in the different groups and therefore specific offers for specific targets are required for the promotional initiatives to be successful.

Following the above-mentioned questions, two open questions were asked in order to invite ideas on other types of discount initiatives and services.

A total of 86 suggestions were collected relating to reduced loss initiatives 66.3 per cent of these concern discounts on products and/or services. There were several propositions: discount on fuel (26.7 per cent), books and magazines (18.6 per cent), vouchers for satellite television subscriptions (2.3 per cent), discounts on motorway tolls (2.3 per cent). Other requests related to discounts on fitness and wellness services (10.5 per cent), clothing (10.5 per cent), entertainment and leisure time (7.0 per cent), sport activities (3.5 per cent), health and culture (1.2 per cent).

A total of 29 suggestions were collected for extra gain initiatives. The most frequent suggestions concerned services usable at the point of sale to improve the shopping experience and facilitating the actual stay in the retail outlet (51.7 per cent). The most frequent suggestions relate to baby-sitting services (10.3 per cent), cash dispensers (6.9 per cent), product tastings prior to purchase (6.9 per cent), different payment options (6.9 per cent) and faster service at counters/checkout desks (6.9 per cent) (Tables IV and $\mathrm{V}$ for details of both promotional areas of the specific discounts and services).

This brings to light how ready the market is for dedicated alternative promotions and initiatives that involve business operators aside from the retailer. The consumer seems to appreciate those initiatives able to produce advantages not only to the consumer goods but also to the day-to-day type of services and purchases.

\section{Conclusions, limits of the research and managerial implications}

The results support the arguments set out. The empirical data shows that the top customers (Group A) are actually less inclined to own several cards and the lower the spending levels of shopping groups are, the more cards customers are inclined to own.

It also emerges that for top customers, loyalty to a card is proportional to loyalty to the retail outlet, which is considered the most important element. However, we cannot 


\section{IJRDM \\ 38,3}

220

\begin{tabular}{|c|c|c|c|}
\hline Type & Reduced loss suggestions & $n^{\circ}$ & Percentage \\
\hline \multirow[t]{2}{*}{ Clothing } & & 9 & 10.5 \\
\hline & Total & 9 & 10.5 \\
\hline \multirow[t]{4}{*}{ Sport } & Horse-riding & 1 & 1.2 \\
\hline & Golf & 1 & 1.2 \\
\hline & Skiing & 1 & 1.2 \\
\hline & Total & 3 & 3.5 \\
\hline \multirow[t]{4}{*}{ Wellness } & Fitness and wellness centre & 2 & 2.3 \\
\hline & Beauty shop & 1 & 1.2 \\
\hline & Hairdresser & 6 & 7.0 \\
\hline & Total & 9 & 10.5 \\
\hline \multirow[t]{2}{*}{ Culture } & Language courses & 1 & 1.2 \\
\hline & Total & 1 & 1.2 \\
\hline \multirow[t]{2}{*}{ Health } & Treatments & 1 & 1.2 \\
\hline & Total & 1 & 1.2 \\
\hline \multirow[t]{16}{*}{ Other products/services } & Vouchers for satellite television subscriptions & 2 & 2.3 \\
\hline & Paying bills & 1 & 1.2 \\
\hline & Flight ticket & 1 & 1.2 \\
\hline & Paying nursery school fees & 1 & 1.2 \\
\hline & Motorway tolls & 2 & 2.3 \\
\hline & Fuel & 23 & 26.7 \\
\hline & Books and magazines & 16 & 18.6 \\
\hline & Stationery store & 2 & 2.3 \\
\hline & Hi fi/home appliances & 2 & 2.3 \\
\hline & Laundry & 1 & 1.2 \\
\hline & Canteen & 1 & 1.2 \\
\hline & Renting videos & 1 & 1.2 \\
\hline & Beach establishments & 1 & 1.2 \\
\hline & Top up cards & 2 & 2.3 \\
\hline & Do it yourself (DIY), gardening & 1 & 1.2 \\
\hline & Total & 57 & 66.3 \\
\hline \multirow[t]{5}{*}{ Entertainment and leisure time } & Amusement park & 3 & 3.5 \\
\hline & Restaurant & 2 & 2.3 \\
\hline & Pop concert, show & 1 & 1.2 \\
\hline & Total & 6 & 7.0 \\
\hline & Total & 86 & 100 \\
\hline
\end{tabular}

\section{Table IV.}

Promotional areas for specific discounts claim that loyalty is created and supported by a loyalty programme. Our study shows that loyalty to a retail outlet precedes loyalty to a loyalty programme. Moreover, loyalty to a retail outlet can never be considered as total in that, in the natural search for alternatives to the convenience goods market, customers tend to select outlets that are considered complementary and the shopping budget is shared among distributors of different formats. Customers select different sales formats where they perceive a clear difference. It seems that retail companies are not yet able to communicate their competitive position clearly. This may drive customers to choose from among different distribution offers. Customer loyalty is basically relative. Within this framework, loyalty programmes do not seem to affect the choice of retail outlet.

When selecting a retail outlet, customers are inclined to maximize all the advantages offered. When studying the motivations behind ownership of a loyalty card, customers are inclined to use all of the benefits, both for point collection and prize promotions. 


\begin{tabular}{|c|c|c|c|c|}
\hline Type & Extra gain suggestions & $n^{\circ}$ & Percentage & marketino and \\
\hline \multirow[t]{6}{*}{ Product } & Home/cookery tools & 1 & 3.4 & lovalty cards \\
\hline & Newspapers and magazines & 1 & 3.4 & \\
\hline & Pharmacy & 1 & 3.4 & \\
\hline & Food for people with celiac disease & 1 & 3.4 & \\
\hline & Tobacco and cigarettes & 1 & 3.4 & 221 \\
\hline & Total & 5 & 17.2 & \\
\hline \multirow[t]{4}{*}{ Promotion } & Points converted into vouchers (for the hairdresser) & 1 & 3.4 & \\
\hline & Points converted into vouchers (for the & & & \\
\hline & entertainment centre) & 1 & 3.4 & \\
\hline & Total & 2 & 6.9 & \\
\hline \multirow[t]{2}{*}{ Proximity/warehousing } & Opening times/extended opening & 2 & 6.9 & \\
\hline & Total & 2 & 6.9 & \\
\hline \multirow[t]{3}{*}{ Social marketing } & Distributing to charity what is unsold & 1 & 3.4 & \\
\hline & Charity sale & 1 & 3.4 & \\
\hline & Total & 2 & 6.9 & \\
\hline \multirow[t]{10}{*}{ In store services } & Bulletin board & 1 & 3.4 & \\
\hline & Baby sitting & 3 & 10.3 & \\
\hline & Cash dispenser & 2 & 6.9 & \\
\hline & Different payment options & 2 & 6.9 & \\
\hline & Pizza home delivery & 1 & 3.4 & \\
\hline & Tasting products before purchase & 2 & 6.9 & \\
\hline & Faster service at counters/checkout desks & 2 & 6.9 & \\
\hline & Mileage allowance & 1 & 3.4 & \\
\hline & Top up cards & 1 & 3.4 & \\
\hline & Total & 15 & 51.7 & \\
\hline \multirow[t]{4}{*}{ DIY/hobbies/leisure time } & Home decoration & 1 & 3.4 & \\
\hline & Consultations and sampling of beauty treatments & 2 & 6.9 & Table V. \\
\hline & Total & 3 & 10.3 & Promotional areas for \\
\hline & Total & 29 & 100 & specific services \\
\hline
\end{tabular}

However, discounts are the most important motivation, which explains, but does not justify, the use of this tactical procedure within loyalty programmes. In fact, managing a loyalty programme in this way is the major reason why programmes lose effectiveness. As expounded by the data provided, customers owning several cards (Segment D) are most likely to be attracted by loyalty discounts, where savings can be optimized by going to several retail outlets.

According to the empirical data, we can argue that:

- owing several loyalty cards discourages loyalty to a particular retail company; and

- when access barriers are weak, price promotions in loyalty programmes increase disloyalty to programmes.

When inquiring into why a card is used and how the interviewed subjects liked the initiatives, it was clear that point collection does not have much appeal and the related initiatives, such as additional bonus points on certain products, are mostly considered of little or insignificant interest. It is interesting to note that this point of view was mainly expressed by Segment A, a group who is supposed to be, as is generally theorized, the least influenced by price and the most inclined towards different forms of reward 
IJRDM

38,3

222 and satisfaction. As for motivation behind loyalty card use, the sample of Segment A are most inclined to discounts, but are also the most "neutral" to loyalty programmes.

This result, which should be studied further, shows how weak and limited the programmes are, especially the point collection programmes.

New ways need to be found to develop programmes that generate appeal and efficacy, significant suggestions came from the card owners themselves.

Suggestions on specific initiatives that customers would like to be included in loyalty programmes show that there is a predominant interest in discounts rather than extra gain promotions. It is worth noting that most of the suggestions concern discounts on products or services that are not directly available at the distributor's outlets and therefore imply a partnership between a retailer and other business operators whom customers usually deal with.

Although not widely mentioned, innovations in available services at a distributor's outlet are another growing area of differentiation for loyalty programmes.

Analysis of what customers expect, and how they behave towards programme innovations, requires further empirical detail. This could be obtained by employing other survey techniques that are more suitable to an in-depth study, such as focus groups, as well as result analyses of a higher number of socio-demographical variables and life-styles. Whilst these reflections require further investigation, we can confirm the third argument we put forward, according to which:

- the more experiential the reward, the more attractive a loyalty programme is.

Customer suggestions on discounts, services related to fitness, wellness, culture, entertainment and life-style improvement indicate that the domestic market is ready for coalition and partnership programmes as a development of the proprietary programme, both in the evolution of mechanisms and in the nature of rewards, which should be experiential rather than functional.

With reference to the empirical results and literature on loyalty marketing and loyalty cards, several managerial implications have emerged.

Programme efficiency can be achieved if there is a continuous search for differentiation, based on mechanisms that are difficult to imitate and the ability to anticipate customers' expectations, by innovating promotional initiatives of reduced loss as well as extra gain:

- In the first case, it is necessary to focus on only the most profitable customers, through micro-marketing strategies and more precise customer segmentation and offer personalization (Lugli and Ziliani, 2004).

- As for the incentive programme, retailers must pick targets carefully and compel them to loyalty by offering differentiated and additional prizes or prizes with higher emotional value for top customers (Cuthbertson, 2006-2007). All the suggestions given by interviewed subjects on services and discounts indicate that the domestic market is ready for multi-brand loyalty programmes. For this reason, proprietary programme partnerships and coalition marketing could be new ways of developing loyalty programmes.

Moreover, we need to focus on a more careful evaluation of the local distribution system, which should not only be considered in cases of new shop openings. In fact, it has been shown that the major indicators of disloyalty, related to the ownership of 
several cards, are positively correlated to the presence of several big brand names in modern distribution.

As for gender, this is an ineffectual variable to explain the ownership of loyalty cards as well as for the motivations in subscribing and using it, elements that are important in defining a loyalty programme mix.

In conclusion, the most significant managerial implications concern constant research of technology innovation, improvement of expertise as well as creativity and imagination (Capizzi et al., 2004) which support the company in using its resources in a new and original way.

This study therefore presents some limitations due to the specific focus on the supermarket loyalty programmes and the analysis of a single Italian company, even if it is one of the biggest Italian food retailer for points of sales and turnover.

Second, the research is limited to a specific region and it reflects the socio-demographic features of retailer's loyal customers.

Moreover, the data we collected are not so recent, even though further analysis that were conducted by the retailer with the same methodology have substantially confirmed the results as valid.

For future researches, further comparisons among different food and non-food retailers could be useful to better understand customers' attitudes and perceptions on loyalty programmes. Qualitative data, collected with focus groups or face-to-face interviews may be useful to improve knowledge on issues driving to satisfaction and dissatisfaction and on expectations about new services and promotions. Including a higher number of socio-demographical and life-style variables may then give some more evidences.

\section{Note}

1. The food retailers mentioned in Tables II and III and in Figure 1 are the biggest ones in Italy. Such retailers are different in format: Iper and Ipercoop, Auchan, Cityper and Iperstanda are hypermarket formats. Sidis, Di Meglio, Sisa, Famila, Despar, GS and Sma are supermarkets or superettes.

\section{References}

Baird, N. (2007), "Coalition loyalty programmes: the next big thing?", Chain Store Age, Vol. 83 No. 7 , p. 14.

Bellizzi, J.A. and Bristol, T. (2004), "An assessment of supermarket loyalty cards in one major US market”, Journal of Consumer Marketing, Vol. 21 No. 2, pp. 144-54.

Berman, B. (2006), "Developing an effective loyalty programme”, California Management Review, Vol. 49 No. 1, pp. 123-4.

Berry, L.L. and Parasuraman, A. (1992), Marketing Services. Competere con la qualità, Sperling \& Kupfer, Milano.

Berry, L.L., Shostack, G.L. and Upah, G.D. (1983), Emerging Perspectives on Service Marketing, AMA, Chicago, IL.

Busacca, A.G. (2002), L'era del cliente, Il Sole 24 Ore, Milano.

Capizzi, M., Ferguson, R. and Cuthbertson, R. (2004), "Loyalty trends for the 21st century", Journal of Targeting, Measurement \& Analysis for Marketing, Vol. 12 No. 3, pp. 199-212. marketing and loyalty cards

223 
IJRDM

38,3

224
Cedrola, E. (2006), "Il customer relationship marketing", in Blythe, J. (Ed.), Fondamenti di Marketing, Pearson Prentice-Hall, Milano, pp. 294-355.

Cuthbertson, R. (2006-2007), "Softly softly: rewarding customer loyalty?", European Retail Digest, Vol. 52, pp. 7-8.

Dowling, G.R. (2002), “Customer relationship management: in B2C markets, often less is more", California Management Review, Vol. 44 No. 3, pp. 87-104.

Dowling, G.R. and Uncles, M.D. (1997), “Do customer loyalty programmes really work?”, Sloan Management Review, Vol. 38 No. 4, pp. 71-82.

Farinet, A. and Ploncher, E. (2002), Customer Relationship Management, Etas, Milano.

Ferrero, G. (1992), Il marketing relazionale. L'approccio delle scuole nordiche, Lint, Trieste.

Friedman, J. (2003), "Loyalty points: do customer rewards programmes deliver?", Incentive, Vol. 177 No. 7, p. 9.

Gable, M., Fiorito, S.S. and Topol, M.T. (2008), "An empirical analysis of the components of retailer customer loyalty programs", International Journal of Retail \& Distribution Management, Vol. 36 No. 1, pp. 32-49.

Grönroos, C. (1990), Service Management and Marketing, Lexington Books, Lexington, MA.

Hawkins, G. (2006), "Retailing in the age of 'T'”, Progressive Grocer, Vol. 85 No. 1, p. 34.

Invernizzi, E. (2000), La comunicazione organizzativa: teorie, modelli e metodi, Giuffrè Editore, Milano.

Kivetz, R., Oleg, U. and Yuhuang, Z. (2006), "The goal-gradient hypothesis resurrected: purchase acceleration, illusionary goal progress and customer retention", Journal of Marketing Research, Vol. 43 No. 1, pp. 39-58.

Lugli, G. (2006), “Collections e valore di marketing”, Creare fedeltà attraverso la partnership, University of Parma, Parma, October.

Lugli, G. and Pellegrini, L. (2005), Il marketing distributivo. La creazione di valore nella distribuzione despecializzata, Utet, Torino.

Lugli, G. and Ziliani, C. (2004), Micromarketing, creare valore con le informazioni di cliente, Utet, Torino.

Magi, A.W. (2003), "Share of wallet in retailing: the effects of customer satisfaction, loyalty cards and shopper characteristics", Journal of Retailing, Vol. 109 No. 2, pp. 1-11.

Mauri, C. (2000), "Fedeltà ... alle carte e fedeltà al negozio: coincidono?”, Le tendenze del marketing in Europa, University Ca' Foscari, Venice, November.

Meyer-Waarden, L. (2007), "The effects of loyalty programmes on customer lifetime duration and share of wallet", Journal of Retailing, Vol. 83 No. 2, pp. 223-4.

Meyer-Waarden, L. and Benavent, C. (2006), "The impact of loyalty programmes on repeat purchase behaviour", Journal of Marketing Management, Vol. 22 Nos 1-2, pp. 61-88.

Rubach, E. (2002), "Loyalty cards vs price cuts: which is more persuasive?", Precision Marketing, Vol. 14 No. 20, p. 2.

Sandberg, K.D. (2002), "What's the cure for customer fatigue?", Harvard Management Update, Vol. 7 No. 7, pp. 6-8.

Sharp, B. and Sharp, A. (1997), "Loyalty programmes and their impact on repeat-purchase loyalty patterns", International Journal of Research in Marketing, Vol. 14, pp. 473-86.

Vence, D.L. (2006), “Create expectations”, Marketing News, Vol. 40 No. 16, pp. 25-8.

Woolf, B. (1996), Customer Specific Marketing: The New Power in Retailing, Raphel Marketing Edition, New York, NY. 
Woolf, B. (2002), Loyalty Marketing: The Second Act, Edizioni Cres, Rome.

Worthington, S. (1996), "Smart cards and retailers - who stands to benefit?", International Journal of Retail \& Distribution Management, Vol. 24 No. 9, pp. 27-34.

Wright, C. and Sparks, L. (1999), "Loyalty saturation in retailing: exploring the end of retail loyalty cards?", International Journal of Retail \& Distribution Management, Vol. 27 Nos 10/11, pp. 429-39.

Ziliani, C. (1999), Micromarketing. Le carte fedeltà della distribuzione in Europa, Egea, Milano.

Ziliani, C. (2004a), "Caratteristiche e limiti dei metodi di misurazione dell'efficacia promozionale", La misura dell'efficacia delle promozioni. Migliorare la performance con le informazioni di cliente, University of Parma, Parma, October.

Ziliani, C. (2004b), “Tendenze e previsioni di sviluppo del micromarketing in Europa”, Il Futuro del Micromarketing, University of Parma, Parma, February.

Ziliani, C. and Bellini, S. (2004), "From loyalty cards to micro-marketing strategies: where is Europe's retail industry heading?", Journal of Targeting, Measurement \& Analysis for Marketing, Vol. 12 No. 3, pp. 281-9.

Ziliani, C. and D'Onofrio, C. (2006), "Le promozioni fedeltà in Italia: efficacia del catalogo e orientamenti strategici", Creare fedeltà attraverso la partnership, University of Parma, Parma, October.

\begin{abstract}
About the authors
Elena Cedrola ( $\mathrm{PhD}$ in "Marketing Research" at La Sapienza University of Rome) is an Associate Professor of Marketing and International Marketing at the University of Macerata (Italy). She also teaches International Marketing at the Catholic University of Milan. Her research and publications are in the areas of internationalization of small and medium enterprises, internet marketing, bank marketing and customer relationship marketing. Elena Cedrola is the corresponding author and can be contacted at: elena.cedrola@unimc.it

Sabrina Memmo ( $\mathrm{PhD}$ candidate in "Communication and Information Theory", at the University of Macerata) is an Assistant Professor at the University of Macerata, where she taught trade marketing. Her research and publications are in the areas of internationalization of small and medium enterprises, trade marketing and customer relationship marketing. In her professional experience she was CRM director at Conad Adriatico.
\end{abstract}

To purchase reprints of this article please e-mail: reprints@emeraldinsight.com Or visit our web site for further details: www.emeraldinsight.com/reprints 